Article

\title{
In What Measure Is Public Finance Sustainability Threatened by Illicit Tobacco Trade: The Case of Western Balkan Countries
}

\author{
Davor Mikulić(D) and Goran Buturac*(D) \\ The Institute of Economics, Zagreb, Trg J.F. Kennedy 7, 10000 Zagreb, Croatia; dmikulic@eizg.hr \\ * Correspondence: gbuturac@eizg.hr; Tel.: +385-1-2362-297
}

Received: 26 November 2019; Accepted: 1 January 2020; Published: 4 January 2020

\begin{abstract}
The aim of this paper is to gain new knowledge about illicit tobacco trade in Western Balkan countries and its effects on public finance sustainability. It includes an estimation of the volume of illicit tobacco trade, identifying and quantifying the key factors that cause illegal tobacco trade, the effects of illegal tobacco trade on public finance sustainability, and the effects on the intensity of total tobacco trade. An empirical analysis was conducted using the data collected by field research on consumer preferences in tobacco products in Western Balkan countries (Bosnia and Herzegovina, Croatia, Kosovo, Macedonia, Montenegro, Serbia, and Slovenia). The reference research period is the year 2018. The results obtained show a high variability of volume of illicit tobacco trade in Western Balkan countries. While more than $20 \%$ of tobacco products in Montenegro and Bosnia and Herzegovina are bought on the gray market, a share of illicit tobacco trade lower than $5 \%$ is found in Slovenia and Macedonia. Underdeveloped institutional framework fighting against illicit trade and weak rule of law, coupled with the heavy taxation of tobacco products, are the key factors behind a higher intensity of illicit trade in comparison to more developed European Union (EU) economies. Illicit tobacco trade negatively affects the stability of public finance of Western Balkan economies and reduces the level of public service. It is especially important for the health system combating the negative consequences of smoking. Regular and illicit tobacco trade amongst Western Balkan countries is found to flow in opposite directions.
\end{abstract}

Keywords: illicit tobacco trade; smuggling theory; public finance sustainability; Western Balkan countries

\section{Introduction}

After decades of political and institutional instability, the Western Balkan (WB) region is currently on track toward building more stable societies, converging to European Union (EU) standards. This situation offers the possibility of strengthening mutual economic cooperation especially in the field of international trade [1,2]. Based on the results from the previous studies on the impacts of trade liberalization and integration processes on macroeconomic performance and export competitiveness [37], it can be assumed that these processes could create new challenges to improve macroeconomic performance and strengthen export competitiveness of Western Balkan countries. These new challenges are reflected, inter alia, in a freer access to international markets with tariffs that were abolished or reduced. However, at the same time, the pressure of competition is growing. Therefore, the competitive effect becomes a dominant factor in stimulating the exports from Western Balkan countries [8]. On the other hand, while observing the negative impacts of illicit trade in these countries, it can be noticed that lower economic development and inadequate institutional capacities of government authorities are some factors behind a more pronounced role in illicit trade in comparison to post-transitional 
economies of new member states (NMS) that joined the EU in the first decade of the 21st century [9-12]. In comparison to NMS, Western Balkan (WB) economies are usually found to lag behind in the quality of the overall institutional environment: the fight against corruption, the efficiency of government units, investments, business, and trade freedom [13].

This sector has a big impact not only on the agricultural activity but also on the economies in the Western Balkan overall, primarily due to the existence of natural resources and a rich tradition in tobacco production and trade. In addition to production and employment, the effects of tobacco production and trade on public finances are particularly interesting and important. Through high taxation, governments try to decrease the prevalence of smoking in the population and collect financial resources for combating health threats related to smoking. The share of total taxes on tobacco products in retail prices could be even above $80 \%$, especially in the developed economies [14]. The difference in prices between the producer and the retail prices, as well as its simple transportation, makes tobacco an item that is most frequently included in illicit trade. The consequences of tobacco smuggling are multidimensional and include negative effects on fiscal sustainability, health issues, social relations, and the development of organized crime.

The aim of this paper is to gain new knowledge about illicit tobacco trade in Western Balkan countries. The key research questions of the paper are as follows: How big is illicit tobacco trade in Western Balkan countries? What are the key factors that cause illegal tobacco trade in these countries? What are the effects of illegal tobacco trade on public finance? In what measure is public finance sustainability in Western Balkan countries threatened by illicit tobacco trade?

The analysis was conducted on the data collected by field research on consumer preferences in tobacco products in Western Balkan countries (Bosnia and Herzegovina, Croatia, Kosovo, Macedonia, Montenegro, Serbia, and Slovenia). The reference research period is the year 2018.

Systematic empirical research on the influence of illicit tobacco trade on public finance sustainability for Western Balkan countries was not previously conducted. However, in addition to several studies on individual countries which mostly deal with tobacco production $[15,16]$, tobacco trade was explored as a part of trading agricultural products between countries from the Balkan region [17]. The contribution of this paper to literature is to gain new scientific knowledge on the influence of illicit tobacco trade on the sustainability of public finances using the sample of the Western Balkans. Despite the limited geographic scope, motivation for contributing to literature stems from the significance of international trade for small open economies and its effects on public finance. Also, some Western Balkan countries were recognized in studies discussed in the literature overview as a hub for illicit tobacco trade, which additionally confirms the importance of this research in terms of new scientific contributions. Due to the fact that the effects of illicit tobacco trade are not only of a financial or economic nature but also have social and health implications, the results obtained in this research can be a good basis for further research not only in economics but also in some other research areas.

After the introductory remarks, Section 2 presents a literature review on the factors behind, and the volume and the consequences of illicit tobacco trade. Section 3 defines survey methodology and describes data sources. The empirical results are presented in Section 4 and are followed by a conclusion and discussion with previous findings in the last section.

\section{Literature Overview}

The illicit trade in tobacco products is defined in Article 1 of the World Health Organization's (WHO) Framework Convention on Tobacco Control as "any practice or conduct prohibited by law and which relates to production, shipment, receipt, possession, distribution, sale, or purchase, including any practice or conduct intended to facilitate such activity" [18]. Illicit trade manifests itself in three major and interrelated ways: smuggled, counterfeit, and local tax-evaded products [19]. Illegal economic activity, such as the illicit trade in tobacco products, distorts local economies and reduces legitimate business and tax revenues [20]. 
The modern smuggling theory started with research from Bhagwati and Hansen [21]. They explored smuggling within the standard international trade model. Many later studies tried to determine the implications of smuggling on economic welfare, looking in particular at the tax evasion aspect of smuggling [22-26]. Pitt extended Bhagwati and Hansen's model by incorporating the concept of price disparity which is defined as the difference between the domestic price and the world priceless tax [23]. It was concluded that legal trade was often used to camouflage illegal trade, and that a greater volume of legal trade resulted in lower costs of smuggling. Since previous studies were deficient in the way they incorporated transport costs into smuggling models, Norton developed a model of smuggling within a European Economic Community (EEC) type of framework [24]. Norton concluded that, if the price disparity between the legally traded goods and the smuggled goods increases, and if the tax is raised to mirror the new differential, then the volume of smuggled goods and the distance they are transported also increase [24]. Meriman et al. extended Norton's model and showed that coordinated multilateral increases in cigarette taxes would result in significantly more tax revenue and less smuggling than unilateral tax increases. Yurekli and Sayginsoy estimated the economic size and the impact on government revenues of cigarette smuggling worldwide and formulated economic policies that can be used to effectively address the problem [27]. They concluded that a tax-induced increase in real retail cigarette prices and an improvement in anti-smuggling law enforcement (as proxied by the corruption indicator) are found to significantly increase government revenues while decreasing global consumption and smuggling. Furthermore, when the tax increase is not accompanied by an improvement in law enforcement, then global smuggling of cigarettes would increase, but governments would still enjoy increased tax revenues.

In the early 1990s, the main type of illicit trade was large-scale cigarette smuggling of well-known cigarette brands. Joossens and Raw emphasized that a change occurred as some major international tobacco companies in Europe and the Americas reviewed their export practices due to tax regulations, investigations, and lawsuits by the authorities [28]. Experience across both advanced and developing economies demonstrates that the key economic drivers influencing the illicit tobacco trade are excessive tax levels, usually resulting in a sharp decline in cigarette affordability, and the willingness of organized crime to supply, given the opportunity to gain large profits from tax avoidance [29]. Prieger and Kulick tested the hypothesis that taxes are not an important factor determining the scale of illicit tobacco trade [30]. They used data from 1999-2013 in the European Union. The results obtained showed that a one-euro increase in tax per pack in a country is expected to increase illicit market share by $5 \%$ to $12 \%$ and increase illicit cigarette sales by $25 \%$ to $120 \%$ of the average consumption.

In most recent studies, measuring illegal tobacco trade was the center of interest for researchers [31-34]. It is methodologically challenging for various reasons. Firstly, it is an illegal activity, and illegal traders are unlikely to record their activities as legal traders do. Also, for security reasons, data on illicit trade are usually difficult to obtain, as law enforcement agencies often prefer not to publicize the scope of their activity. Furthermore, all methods to estimate illicit trade have their limitations, and not all studies clearly describe their methodology or these limitations. The three most commonly used methods to measure illicit trade are (a) the comparison of tax paid sales and individually reported consumption measures, (b) a survey of tobacco users purchase behavior, and (c) observational data collection (e.g., the collection of discarded cigarette packs).

Calderoni estimated the illicit cigarette market at the subnational level using the example of Italy [32]. The regional estimates for Italy reveal that the illicit trade varies significantly across time and regions. Also, the results obtained showed that even a strong presence of the mafia in a region is not a sufficient condition for the growth of the illegal trade of tobacco products (ITTP). This contrasts with the opinion of the media and public agencies, which frequently attribute illicit tobacco trade to organized crime. This suggests that illicit cigarettes have a complex market which is influenced by a number of factors.

The Research Center on Transnational Crime (Transcrime) also conducted several studies on the illicit trade of tobacco products (ITTP) [35,36]. Among the most recent ones, it published the series 
"The Factbook on the Illicit Trade in Tobacco Products", with the aim of providing an innovative instrument to shed light on the complex mechanisms behind the illicit trade in tobacco products in different countries. To date, the Factbook series comprises seven reports: the United Kingdom, Italy, Ireland, Poland, Germany, Lithuania, and Spain. In 2015, the Center also published the European Outlook on the illicit trade in tobacco products (ITTP), a study on the ITTP in 28 European Union (EU) countries. In its first part, the report analyzes selected components of the illicit cigarette market in the $\mathrm{EU}$; in the second one, it examines in detail the illicit markets within each EU Member State, as well as the role of selected non-EU European countries in the EU illicit market.

Some of the latest research is focused on the key hubs which are crucial sets of countries on the regional, continental, or global map of the illicit trade in tobacco products [34,37]. The analysis of these key hubs instead of single countries enables a more comprehensive understanding of the factors determining the transnational illicit flows and a more effective identification of the strategies to fight and prevent the ITTP [34-38].

\section{Methods}

The empirical analysis conducted in the next chapter is based on the data collected by field research on the sample of seven countries from the Western Balkans: Bosnia and Herzegovina, Kosovo, Croatia, the former Yugoslav Republic of Macedonia, Montenegro, Serbia, and Slovenia. The reference research period is the year 2018. Although Slovenia is usually not classified as WB economy, due to its geographical proximity and common historical background, it is also included in the sample. A stratified sampling procedure was applied, with geographical region, age, and gender as control variables. The raw data collected were tested, and logical control was performed. Light weighting was applied in Croatia and Slovenia due to a low response rate. The sample size was limited by available resources, and the data include responses of approximately 21,000 adult respondents (approximately 3000 per country). Quality control was performed by re-contacting the respondents and cross-checking answers of over $25 \%$ of the interviews. Statistical procedures of sample stratification and quality control described above could contribute to the reliability of the survey results. The sample size and the gender, age, and education structure of the respondents are presented by Table 1 . The characteristics of the samples in individual countries do not significantly differ from the population and can be considered representative. The questionnaire was designed to gradually explore smoking prevalence, the quantity of tobacco products usually consumed per day, the buying habits, and attitudes toward various factors influencing smoking habits.

Table 1. The structure of survey respondents by gender, age, and education level.

\begin{tabular}{lccccccc}
\hline & Croatia & Slovenia & $\begin{array}{c}\text { Bosnia and } \\
\text { Herzegovina }\end{array}$ & Serbia & Montenegro & Macedonia & Kosovo \\
\hline Number of respondents & 3000 & \multicolumn{7}{c}{3008} & 3000 & 3000 & 3000 & 3000 & 3000 \\
\hline \multicolumn{7}{c}{ Gender structure, in \% of total } \\
\hline Male & 47.5 & 49.3 & 50.0 & 50.0 & 51.8 & 49.7 & 50.3 \\
\hline Female & 52.5 & 50.7 & 50.0 & 50.0 & 48.2 & 50.3 & 49.7 \\
\hline \multicolumn{7}{c}{ Age structure, in \% of total } \\
\hline 18-34 & 27.1 & 28.5 & 26.6 & 28.1 & 32.0 & 34.0 \\
\hline $35-54$ & 34.4 & 35.9 & 36.1 & 33.2 & 32.4 & 35.9 & 44.0 \\
\hline $55+$ & 38.6 & 40.6 & 34.9 & 40.1 & 39.5 & 32.1 & 22.0 \\
\hline \multicolumn{7}{r}{ Education structure, in \% of total } \\
\hline Elementary school or lower & 7.5 & 4.9 & 9.3 & 10.7 & 4.9 & 15.6 & 45.3 \\
\hline High school & 58.3 & 51.2 & 67.9 & 62.9 & 68.0 & 59.3 & 48.3 \\
\hline College, university, or higher & 34.2 & 44.0 & 22.8 & 26.4 & 27.1 & 25.1 & 6.4 \\
\hline
\end{tabular}

Source: Authors' processing according to the survey conducted by the Institute of Economics, Zagreb. 
When the volume of illicit tobacco trade estimated by a direct survey is compared to other methods (for example, observation of littered cigarette packs), it usually provides a lower boundary due to potential bias related to intentional misreporting by survey respondents. The issuance of potential distortions in surveys which include sensitive questions involving illicit tobacco trade was discussed in Tourangeau and Yan [39]. They suggested that misreporting in the case of sensitive topics is quite common and depends on whether the respondents edit the information they report in order to avoid embarrassing themselves or to avoid repercussions from third parties. The question about personal experience with illegal tobacco trade is related to the traditional concept of social (un)desirability. A person could refuse to answer if they perceive that an honest answer could be socially unacceptable or undesirable [39]. Therefore, results presented in the next chapter should be considered as a lower boundary of the volume of illicit tobacco trade.

In addition to the information on the share of smokers in the total population, the survey data on tobacco use include questions on tobacco products bought on the gray market. Buyers of tobacco products were asked if they usually buy products domestically or abroad and if purchases were made on the regular or gray market. Usual distribution channels of tobacco supply on the gray market are separated on the following items:

- From resellers on the street;

- From resellers in a house;

- At the store or stand, but under the counter;

- From friends and acquaintances;

- On the internet;

- Other.

A person residing close to the international border sometimes may buy tobacco products for personal consumption in a neighboring country because of lower taxation. Generally, it is not to be treated as an illegal transaction. Importing products in limited quantities for own personal consumption is usually allowed by national legislation. On the other hand, importing tobacco products for the purpose of reselling at higher prices should be treated as illegal activity; nevertheless, it could be a small-scale operation in the form of supplying friends and acquaintances. In addition to the small-scale tobacco smuggling to friends and acquaintances, the more severe form of informal tobacco supply is related to organized distribution of products on the street, in a house, or under the counter.

In order to estimate the total amount and value of tobacco products bought on certain market segments, the following procedure was applied:

(a) The number of smokers in each WB state was based on smoking prevalence estimated from the WB survey and applied to the adult population;

(b) Regarding usual market place and relative distribution of answers in the survey, smokers were divided into the following groups:

smokers usually buying on the regular domestic market;

smokers usually buying on gray domestic market;

smokers usually buying abroad;

(c) The quantity of products for each group of smokers was based on the self-declaration on the quantity of tobacco product usually smoked per day;

(d) The total value of tobacco products bought on the regular market was estimated by the multiplication of quantities and the price of the typical tobacco product with a dominant share on the domestic market;

(e) The total value of tobacco products bought on the gray market was estimated by the multiplication of the quantity and unit price of tobacco products on the gray market estimated from the survey;

(f) The unit trade margin related to tobacco smuggling was estimated as the difference between the unit price realized on the gray market and unit producer or import price on the local market. 
Some of the previous studies applied a residual model where published smoking rates after correction for the impact of other significant factors were compared to legal paid sales of cigarettes [40]. A residual model based on the smoking prevalence of the domestic population would certainly underestimate the overall level of illicit tobacco trade if applied to Western Balkan countries recording significant foreign tourists' receipts such as Croatia, Montenegro, and Slovenia. Foreign tourists are more likely to buy tobacco through official channels and legal sales of cigarettes for their consumption. On the other hand, any estimate of the average smoking prevalence of foreign tourists arriving from all over the world is highly unreliable. In addition, a residual model would result in incomparable results between countries where tourism is important and other WB countries.

Limiting the analysis period to only one year does not allow trends to be surmounted, factors that produce influences in the medium term to be recognized, training effects to be identified, or relevant correlations and sustainable causalities to be captured.

\section{Results and Discussion}

The volume of illicit tobacco trade and tobacco tax evasion was estimated by the projection of survey results to the total population. The results also compare the intensity of regular tobacco trade and gray import between the sampled countries. Appendix A presents the distribution of answers from the respondents for the most important items on smoking prevalence and experience in illicit tobacco trade presented in the results. The survey consisted of a total of 43 questions.

\subsection{Volume of Illicit Tobacco Trade in WB Region}

The tobacco use survey indicates that smoking prevalence in WB region was the highest in Bosnia and Herzegovina and Kosovo. The key parameters used to estimate the quantity illicit tobacco trade are presented by Table 2 . The lowest share of smokers in the adult population (persons aged 18 or older) was reported for Slovenia, while smoking prevalence was the highest in Bosnia and Herzegovina. Slovenians also reported having the lowest quantity of tobacco products usually smoked per day, while persons from Kosovo and Montenegro reported the highest smoking intensity.

In addition to industrially manufactured cigarettes, in Croatia, Slovenia, Montenegro, and Bosnia and Herzegovina, a significant proportion of smokers reported usually using cut tobacco which they rolled in cigarettes themselves.

The most important indicator used in the estimation of income related to illicit tobacco trade was the share of smokers who reported they usually buy tobacco on the gray market. The highest share of smokers buying illicit tobacco was reported for Montenegro (27.9\%) and Bosnia and Herzegovina (20.3\%). On the other hand, only 3.3\% of Slovenians and 3.8\% of Macedonians bought tobacco on the gray market. The higher living standard and better institutional framework explain the low propensity to buy tobacco products on the gray market in Slovenia. The less developed gray tobacco market in Macedonia is probably related to the lowest retail prices of tobacco products on the regular market.

The regular retail tobacco prices expressed as a percentage of average retail prices in the European Union market are presented in Table 3. 
Table 2. Main survey results on smoking prevalence, smoking intensity, and propensity to buy tobacco on the gray market.

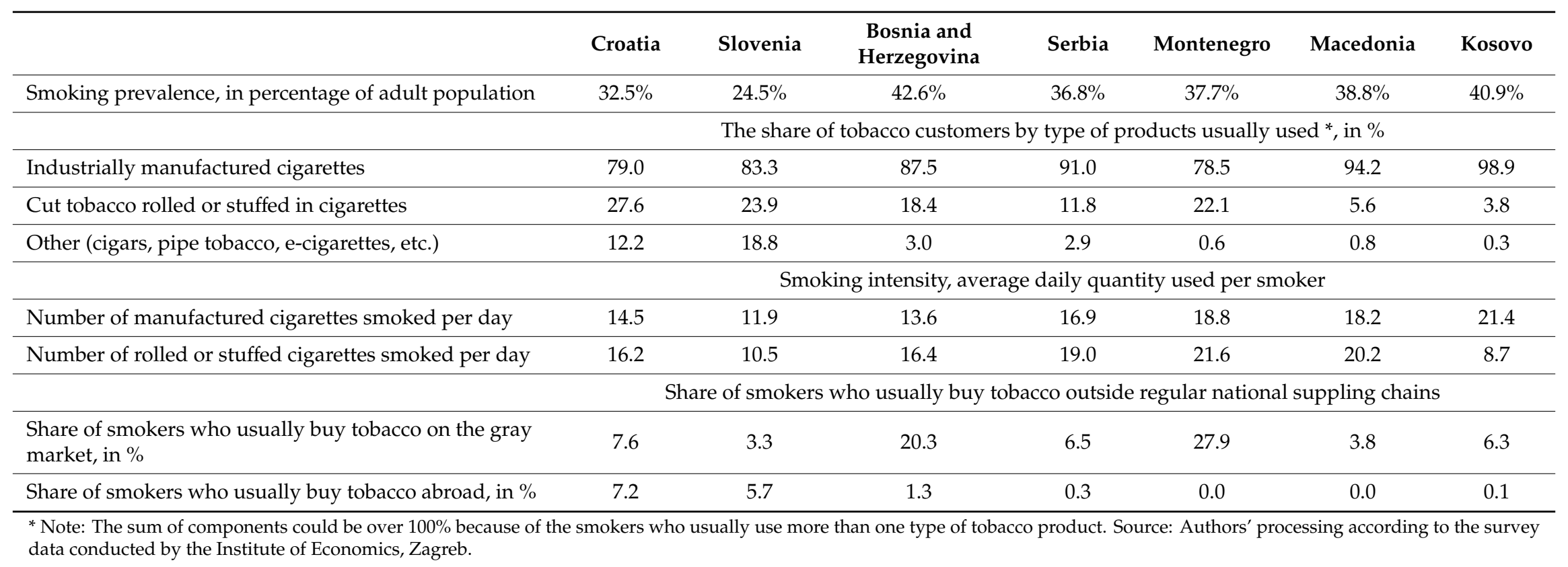


Table 3. The price level of tobacco products on the regular market (European Union $28($ EU28) = 100); n.a.-not available.

\begin{tabular}{lcccccccc}
\hline & $\mathbf{2 0 1 1}$ & $\mathbf{2 0 1 2}$ & $\mathbf{2 0 1 3}$ & $\mathbf{2 0 1 4}$ & $\mathbf{2 0 1 5}$ & $\mathbf{2 0 1 6}$ & $\mathbf{2 0 1 7}$ & $\begin{array}{c}\text { The Price of a 20-Cigarette Pack of the } \\
\text { Most Popular Brand, in euros, in 2016 }\end{array}$ \\
\hline Croatia & 59.2 & 57 & 60.4 & 57 & 55.3 & 55.9 & 56.9 & 3.2 \\
Slovenia & 67.4 & 67.3 & 70.6 & 69.5 & 67.7 & 67.6 & 68.6 & 3.5 \\
Montenegro & 29.5 & 34.2 & 34.7 & 35.4 & 34.5 & 35.6 & 38.8 & 1.7 \\
FYR Macedonia & 26.9 & 25 & 24.7 & 24.6 & 25.1 & 26.7 & 28.6 & 1.1 \\
Serbia & 30.8 & 30 & 37.3 & 38 & 34.3 & 36.9 & 40 & 1.9 \\
Bosnia and Herzegovina & 32.5 & 34.3 & 35.7 & 35.1 & 36.4 & 39.7 & 41.4 & 2.3 \\
Kosovo & n.a. & n.a. & 33.2 & 32.4 & 32.7 & 35.5 & 40 & 2.0 \\
\hline
\end{tabular}

Source: Eurostat database for the price level in the period 2011-2017 and the World Health Organization (2017) for the price of the most popular brand.

Table 3 also presents prices of the most popular brands according to World Health Organization (WHO) data on tobacco control. The prices of the most popular tobacco brands in Croatia and Slovenia were approximately three times higher in comparison to Macedonia and $50 \%$ more expensive in comparison to other WB economies. Price differentials between EU members and other WB economies in the past period were even more pronounced. While tobacco prices in Slovenia and Croatia satisfied minimal EU tobacco tax requirements a decade ago, other WB countries gradually increased tobacco taxation in the analyzed period. An increase in taxation was a part of the overall process of harmonization toward EU legislation. Tobacco prices in Croatia were in 2011 almost double the prices recorded in Bosnia. As a result of the increase of excises in Bosnia, in 2017, the price differential to Croatia dropped to lower than $50 \%$.

Because of the significant price differential not only for tobacco products, but also for other heavily taxed products such as oil derivatives or alcohol, it is not unusual that Croatians living near the Bosnian or Serbian border go "shopping" over the border. A certain percentage of Slovenians were also reported to buy tobacco in Bosnia and Serbia although Slovenia does not directly border those countries. Buyers from Slovenia and Croatia are included in the total demand for tobacco products in Bosnia and Herzegovina. As specified in the methodological part of the paper, this type of tobacco acquisition is strictly speaking not to be treated as illegal, but it certainly affects the volume of tobacco taxes collected in Croatia and Slovenia. Table 4 presents an origin-destination matrix of tobacco products acquired by cross-border purchases between WB economies. Smokers from Macedonia, Montenegro, and Kosovo did not state that they went to purchase tobacco abroad.

Table 4. Cross-border purchases of tobacco products. WB-Western Balkan.

\begin{tabular}{|c|c|c|c|c|c|}
\hline \multirow{2}{*}{$\begin{array}{l}\text { Quantity, in Millions of Cigarettes } \\
\text { Origin, cigarettes bought on the territory of } \\
\text { Bosnia and Herzegovina }\end{array}$} & \multicolumn{5}{|c|}{ Destination, Buyers from } \\
\hline & 329 & 90 & 0 & 25 & 444 \\
\hline Slovenia & 28 & 0 & 5 & 0 & 34 \\
\hline Croatia & 0 & 46 & 57 & 0 & 103 \\
\hline Macedonia & 0 & 0 & 10 & 0 & 10 \\
\hline Total & 488 & 200 & 88 & 38 & 816 \\
\hline
\end{tabular}

Source: Authors' processing according to the survey data conducted by the Institute of Economics, Zagreb.

Smokers who bought tobacco products on the gray market were asked in a survey to provide information on the quantity and the amount they usually spend for that purpose from which gray market prices could be calculated. Figure 1 demonstrates price differentials as a motivation to buy on the gray market. 


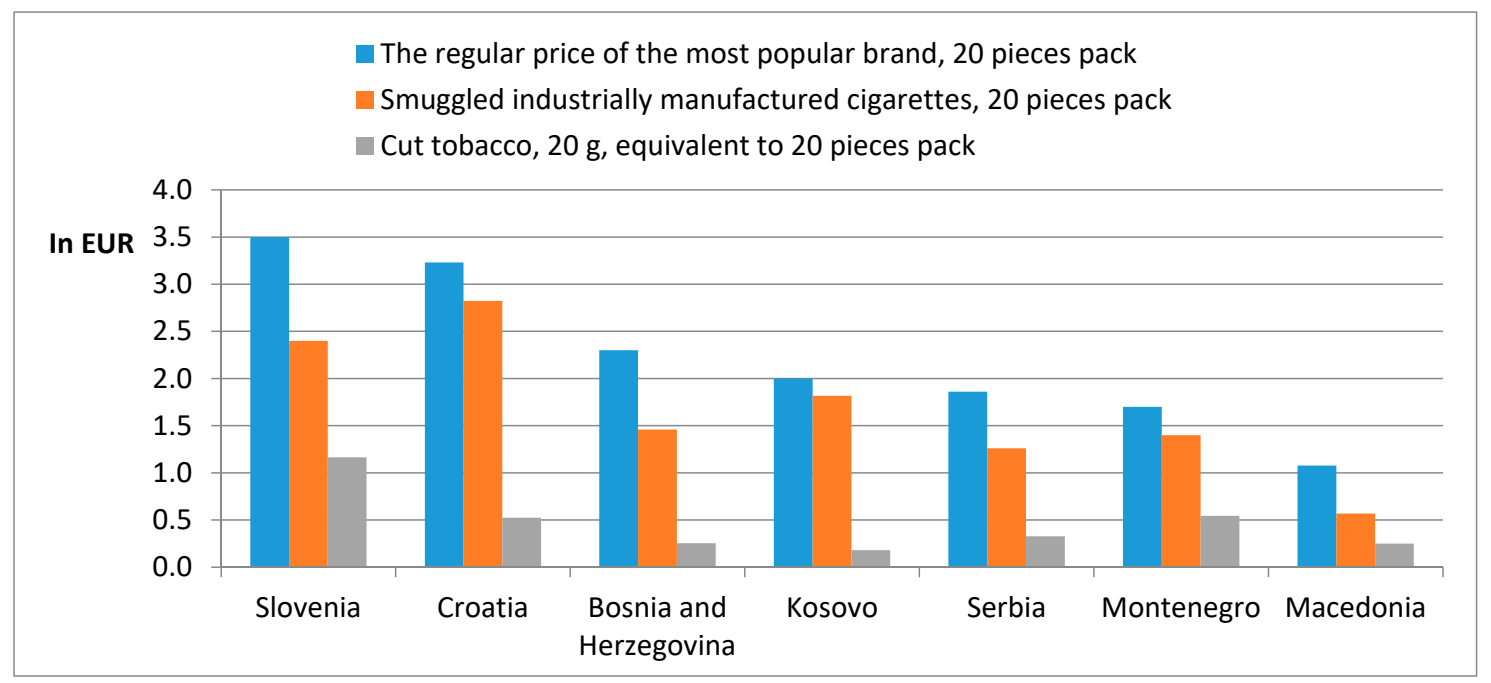

Figure 1. Price differential of tobacco products on the regular and the gray market. Source: World Health Organization (WHO) for the price of the most popular brand; authors' processing according to the survey data conducted by the Institute of Economics, Zagreb.

Prices of packs containing 20 pieces of industrially manufactured cigarettes were lower by $10 \%$ to even $50 \%$ on the illicit market in comparison to regular prices of the most popular brand. The equivalent quantity of cut tobacco ( $1 \mathrm{~g}$ of cut tobacco is assumed to roll up in a cigarette) was 10 times less expensive than a pack bought on the regular market. A high proportion of smokers in WB economies use cut tobacco in order to compensate for high prices of industrially manufactured cigarettes.

Based on the percentage of smokers buying on the gray market and prices of illicit industrially manufactured cigarettes and cut tobacco, an estimate of total expenditures on the gray market was calculated. The producer or import price of cigarettes (without taxes) generally formed only $10 \%$ of the retail market price. The difference between the price achieved on the gray market and the producer's price presented an illegal trade margin retained by traders organized in the distribution channel of illicit tobacco trade. The gross value added related to tobacco smuggling was based on the assumption that the total costs of the tobacco bought for resale on the gray market and the intermediate consumption (the costs of transportation and similar costs incurred by the smuggler industry) presented $20 \%$ of revenues derived by smuggling activity. Table 5 presents an estimate of illegal value added of tobacco smuggling, both in monetary and relative terms.

Table 5. An estimate of illegal income derived from tobacco smuggling.

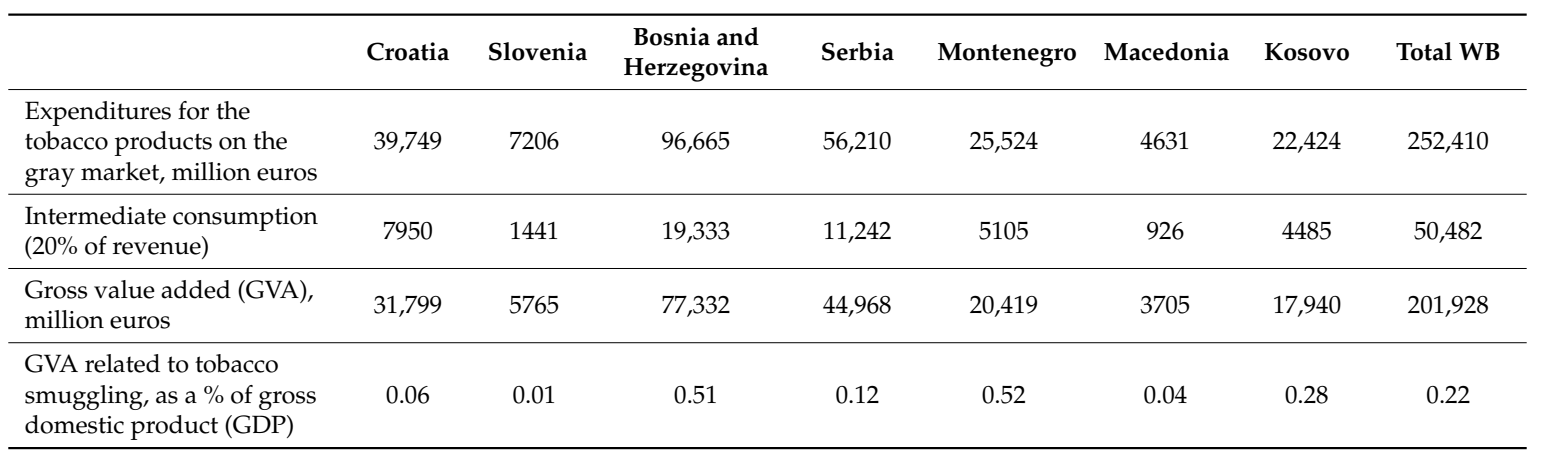

Source: Author's calculations based on the survey results of the Institute of Economics, Zagreb.

In total WB area, income derived by illicit tobacco trade was estimated to over 200 million euros and constituted on average $0.22 \%$ of gross domestic product (GDP). In Bosnia and Montenegro, tobacco smuggling presented over $0.5 \%$ of GDP, while the lowest share was estimated for Slovenia. 


\subsection{The Effects of Illicit Tobacco Trade on Public Finance}

The importance of tobacco smuggling in the overall tax evasion differed among WB economies. Total tax losses include both tax avoidance and tax evasion. While tax avoidance is defined as legally allowed deductions or procedures which reduce tax burden but are not forbidden by law, tax evasion is related to illegal and deliberate misreporting of economic activities to the tax authorities. In the context of tobacco use, when a person buys a product on the foreign market due to lower prices and lower taxation, but in quantities which are allowed to be brought into the domestic economy according to customs regulations, it should be treated as legal tax avoidance. Smokers realize savings due to lower prices, but no income is to be imputed in the national accounts as a result of a transaction of that kind. However, where macroeconomic effects of a potential increase in taxation of tobacco product are in question, it should account not only for tax evasion but also for the legal tax avoidance due to cross-border shopping. The price differential of tobacco products bought in different channels by Croatian consumers is depicted by Figure 2 .

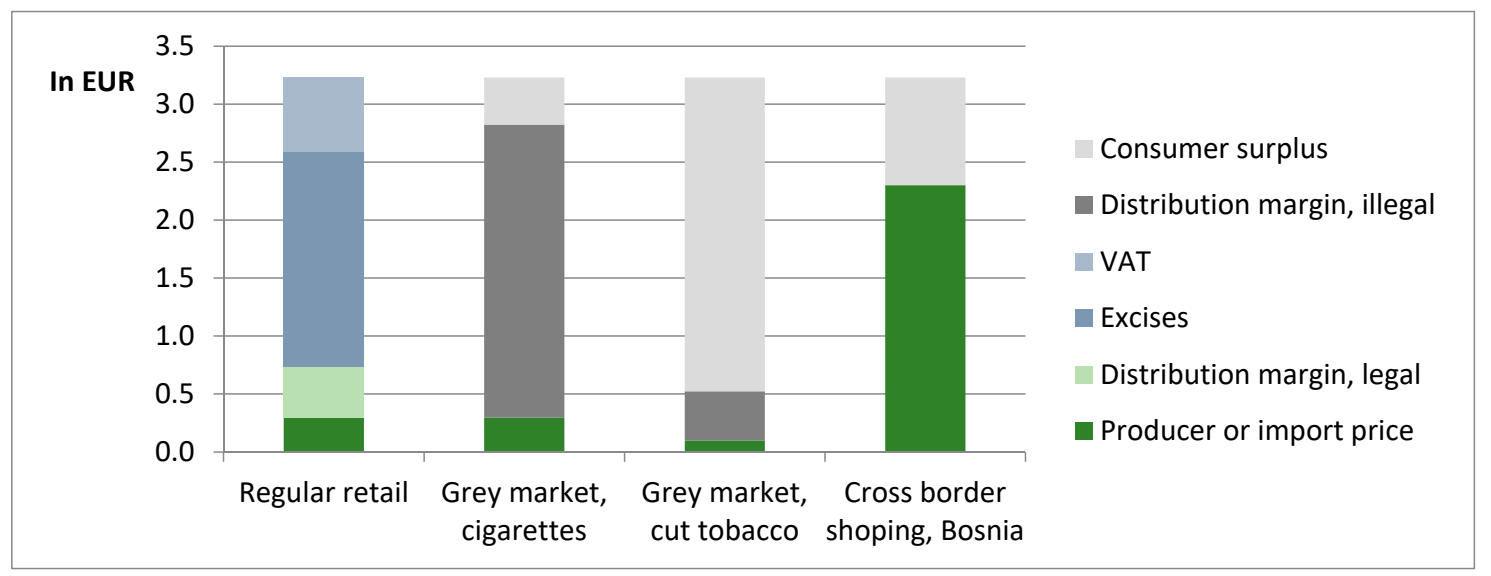

Figure 2. The structure of tobacco prices on the regular retail market and informal supply channels in Croatia, price in euros per 20-piece pack (the most popular brand). Source: Authors' processing according to the survey data conducted by the Institute of Economics, Zagreb.

In the regular retail price of the most popular tobacco brand in Croatia (3.2 euros or 24 Croatian kuna (HRK)), tobacco excises and value added tax (VAT) participate with approximately $80 \%$ (2.5 euros). The production costs and distribution margins (transport and trade margins) amount to only 0.7 euros. The techniques of the acquisitions and distribution of illegal cigarettes for resale on the gray market are beyond the scope of this research, but it is reasonable to assume that distributors are able to acquire tobacco products at a price close to the producer's or import price. As in the case of value-added chain on the regular market, illegal distributers are also specialized in terms of economic functions to importers, wholesalers, transporters, and retailers. Nevertheless, with regard to the exact type of distributional network applied on the illegal market, total income of illegal distributors involved in tobacco smuggling could be approximated as a difference between prices achieved on the gray market and producer or import prices. The final user of gray tobacco products bought on the illegal market achieves consumer surplus in the form of financial savings resulting from at least $10 \%-15 \%$ lower price. Benefits related to tax evasion are actually divided between smugglers and final consumers, probably in favor of smugglers due to higher risks and potential losses related to penalties and seizures if detected by inspections.

In the case of cut tobacco, according to the survey results, the equivalent quantity of tobacco $(20 \mathrm{~g})$ is much more affordable than cigarettes on the gray market and is more often bought from friends or acquaintances. The producer's price of cut tobacco is significantly lower than industrially manufactured cigarettes. Generally, smokers oriented to the gray cut tobacco market benefit more through consumer surplus (financial savings), while the illegal distribution margin is significantly 
lower in comparison to the margin related to smuggling industrially manufactured products. Finally, when a smoker buys a product abroad due to lower taxation, they realize consumer surplus equivalent to the difference between retail prices on the domestic market and abroad. In that case, the domestic government does not receive any tax revenues; however, if bought on the regular retail market, excises and other taxes paid abroad are redistributed to the budget of neighboring country as a part of the price of the tobacco bought.

Based on the WB survey results and the price structure on the regular and gray market, the total value of tax evasion could be calculated (Table 6). Although strictly speaking, purchases abroad in quantities allowed by the national legislation are not to be treated as tax evasion, they should also be included in the broader concept of potential government revenues. If the price of tobacco increases, tobacco sales on the regular domestic market would decrease because of tax evasion but also because of cross-border shopping (legal tax avoidance), and both factors impact government revenues.

The negative effects of tobacco smuggling in terms of taxes evasion and legal tax avoidance related to cross-border shopping are more significant than the effects in terms of gross value added. In absolute monetary terms, potential increase of tobacco taxes in WB region were estimated at almost 400 million euros. In Bosnia and Herzegovina and Croatia, illegal tobacco trade and legal tax avoidance were estimated at over 100 million euros. In relative terms, the share of uncollected tobacco taxes in overall tax evasion was the highest in Bosnia and Herzegovina, Montenegro, and Croatia. The more affordable tobacco prices in Macedonia were the factor behind the relatively low tobacco tax evasion.

\subsection{Regular and Illicit Tobacco Trade Flows among WB Countries}

The greatest part of regular tobacco trade of the Western Balkan Countries was realized in Serbia, Croatia, and Macedonia. These countries recorded a value of export of over 100 million euros, while exports from other WB economies were negligible (Table 7). The cumulative export share of other economies of the WB region (Bosnia and Herzegovina, Kosovo, Montenegro, Slovenia) presented only $15 \%$ of the total WB tobacco exports. The analysis of mutual trade showed that the Western Balkan Countries traded the most with cigarettes, while unmanufactured tobacco and tobacco extracts and tobacco essences had a smaller role in mutual trade structures. The biggest mutual tobacco trade was realized between Serbia and Bosnia and Herzegovina.

It is interesting to compare the directions of regular tobacco exports and gray exports related to cross-border shopping along to the survey results on the share of illicit trade. Figure 3 presents net trade (exports minus imports) for significant trade routes (value over five million euros or quantity over 10 million cigarettes).

It can be found that regular and illicit flows were in most cases performed in different directions. While Croatia is officially the net exporter of tobacco products to Bosnia and Herzegovina and Serbia, gray exports flowed in the opposite direction from Bosnia and Serbia to Croatia. The same conclusion can be drawn for tobacco trade between Serbia and Bosnia. While official statistics recorded Serbia as a net exporter of tobacco products to Bosnia and Montenegro, via informal channels, tobacco products from Bosnia and Montenegro were delivered to Serbia. 
Table 6. Tobacco taxes uncollected due to tax evasion and tax avoidance.

\begin{tabular}{|c|c|c|c|c|c|c|c|c|}
\hline & Croatia & Slovenia & $\begin{array}{c}\text { Bosnia and } \\
\text { Herzegovina }\end{array}$ & Serbia & Montenegro & Macedonia & Kosovo & Total WB \\
\hline $\begin{array}{l}\text { Tax evaded due to tobacco smuggling, } \\
\text { thousand euros }\end{array}$ & 59,215 & 8548 & 129,072 & 64,718 & 23,280 & 6242 & 15,694 & 306,769 \\
\hline Value added tax (VAT) & 15,341 & 1960 & 22,201 & 13,910 & 4973 & 1343 & 3825 & 63,553 \\
\hline Excises & 43,875 & 6588 & 105,187 & 50,808 & 18,307 & 4899 & 11,104 & 240,768 \\
\hline Import duties & - & - & 1684 & - & - & - & 765 & 2449 \\
\hline $\begin{array}{l}\text { Legal tax avoidance related to cross border } \\
\text { shopping, thousand euros }\end{array}$ & 60,829 & 15,404 & 8545 & 2715 & - & - & 128 & 87,621 \\
\hline VAT & 15,759 & 3532 & 1470 & 583 & - & - & 31 & 21,375 \\
\hline Excises & 45,070 & 11,872 & 6964 & 2131 & - & - & 90 & 66,127 \\
\hline Import duties & - & - & 112 & - & - & - & 6 & 118 \\
\hline $\begin{array}{l}\text { Total tobacco tax evasion + legal tax avoidance, } \\
\text { thousand euros }\end{array}$ & 120,044 & 23,952 & 137,617 & 67,433 & 23,280 & 6242 & 15,822 & 394,390 \\
\hline VAT & 31,100 & 5492 & 23,671 & 14,493 & 4973 & 1343 & 3856 & 84,928 \\
\hline Excises & 88,945 & 18,460 & 112,151 & 52,939 & 18,307 & 4899 & 11,195 & 306,896 \\
\hline Import duties & - & - & 1796 & - & - & - & 771 & 2567 \\
\hline $\begin{array}{l}\text { Total tobacco tax evasion + legal tax avoidance, as } \\
\text { a share of GDP }\end{array}$ & 0.2 & 0.1 & 0.9 & 0.2 & 0.6 & 0.1 & 0.2 & 0.3 \\
\hline
\end{tabular}

Source: Authors' processing according to the survey data conducted by the Institute of Economics, Zagreb. 
Table 7. Mutual tobacco trade-export matrix, in thousand euros.

\begin{tabular}{|c|c|c|c|c|c|c|c|c|c|c|}
\hline & $\begin{array}{c}\text { Bosnia and } \\
\text { Herzegovina }\end{array}$ & Croatia & Macedonia & Montenegro & Serbia & Slovenia & $\begin{array}{c}\text { WB } \\
\text { Countries }\end{array}$ & $\begin{array}{c}\text { Other } \\
\text { Economies }\end{array}$ & $\begin{array}{c}\text { Total Export } \\
\text { Abroad }\end{array}$ & $\begin{array}{l}\text { Share of WB in Total } \\
\text { Tobacco Exports }\end{array}$ \\
\hline Bosnia and Herzegovina & - & 56 & 458 & 2230 & 717 & 59 & 3520 & 4808 & 8328 & 42.3 \\
\hline Croatia & 8910 & - & 3599 & 457 & 8588 & 1533 & 23,087 & 90,623 & 113,710 & 20.3 \\
\hline Macedonia & 1438 & 2446 & - & 0 & 6551 & 488 & 10,923 & 130,099 & 141,022 & 7.7 \\
\hline Montenegro & 0 & 331 & 145 & - & 66 & 0 & 542 & 283 & 825 & 65.7 \\
\hline Serbia & 15,495 & 903 & 12,478 & 11,279 & - & 0 & 40,155 & 214,849 & 255,004 & 15.7 \\
\hline Slovenia & 78 & 1172 & 0 & 162 & 106 & - & 1518 & 311 & 1829 & 83.0 \\
\hline WB countries & 25,921 & 4908 & 16,680 & 14,128 & 16,028 & 2080 & 79,745 & 440,973 & 520,718 & 15.3 \\
\hline
\end{tabular}

Source: Authors' calculations based on United Nations (UN) Comtrade and International Trade Center (ITC) statistics. 


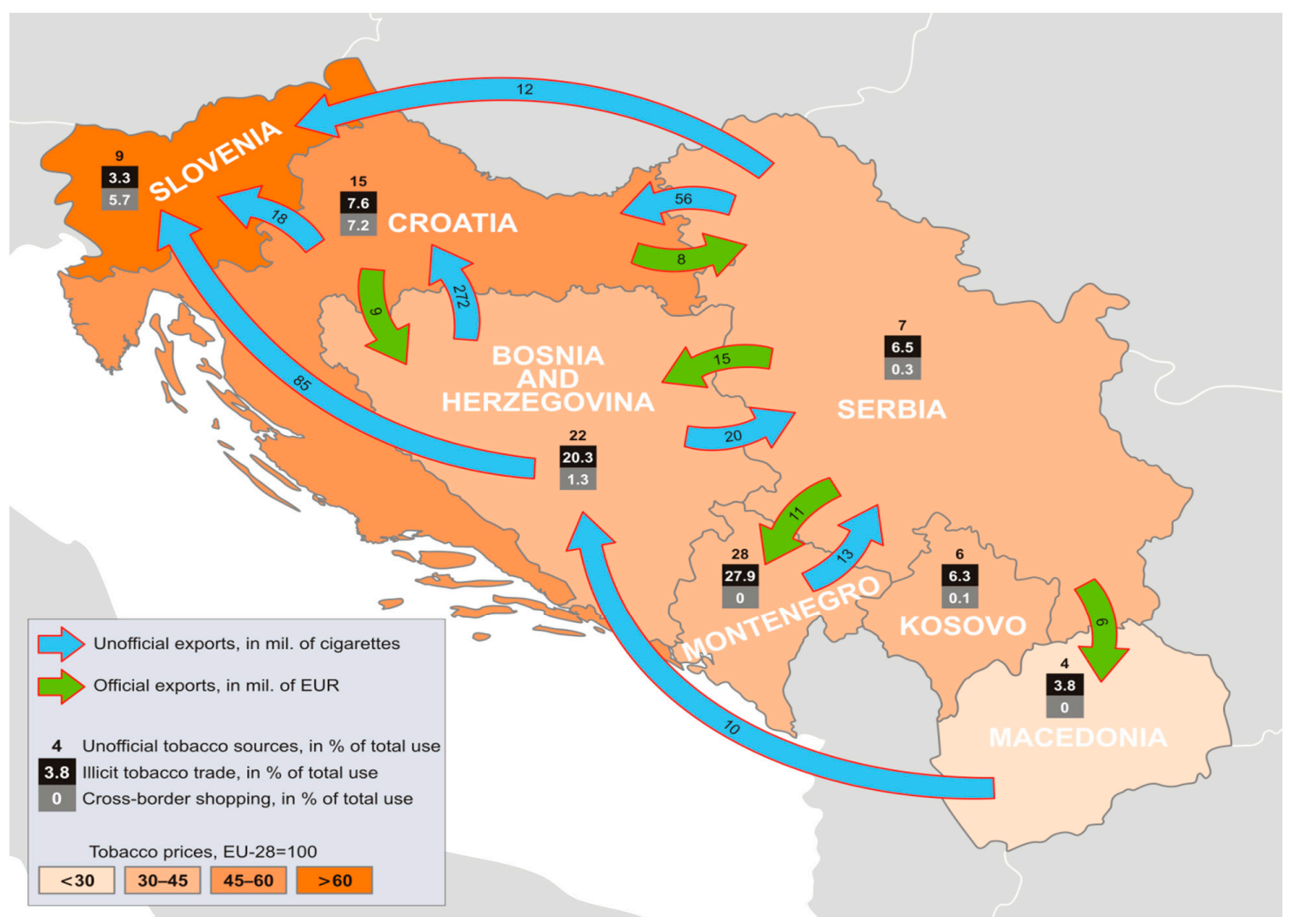

Figure 3. Official and unofficial tobacco trade flows among Western Balkan countries. Source: Authors' processing according to the survey data conducted by the Institute of Economics, Zagreb.

\section{Conclusions}

A high share of taxes in retail price and easy transportation make illicit trade of tobacco a potentially lucrative activity for underground entrepreneurs. Underdeveloped institutional capacities of public inspectorates, a relatively low development level, and weak rule of law in some Western Balkan economies are factors behind the expectation that the range of illicit tobacco trade is broader in comparison to more developed EU economies. Those expectations were confirmed by the survey conducted in WB region which was analyzed in this study. The results obtained allowed determining the answers to the key research questions mentioned in the introduction of the paper.

While Joossens estimated that $12.7 \%$ of cigarette consumption in low- and middle-income countries is illicit, our results indicate that over $20 \%$ of tobacco products in Montenegro and Bosnia and Herzegovina were bought on the gray market [31]. On the other hand, the lowest share of illicit tobacco trade was found in Slovenia and Macedonia.

Previous studies rarely included estimates of illicit tobacco trade for the WB region. Euromonitor International provided estimates for Bosnia and Herzegovina, Serbia, and Macedonia [38]. While our results indicate a more intensive share of illicit trade in Bosnia and Herzegovina (20.3\% in this paper in comparison to $14.2 \%$ found in Euromonitor International), our results for Serbia were below the previous results (6.5\% compared to $11.7 \%$ found in Euromonitor International) [38]. Both studies indicate the low share of illicit tobacco trade in Macedonia which can be explained by the lowest taxation and, as a result, the lowest retail tobacco price. Those findings are in line with Prieger and Kulick who concluded that the role of prices in stimulating illicit tobacco trade is more important than the quality of institutional framework measured by the corruption perception index [30].

Illicit tobacco trade negatively affects the fiscal position of WB economies, which is especially important in the context of government endeavors to ensure the stability of public finance and improve the level of public services, especially when the health system fighting against hazardous health 
consequences of smoking is in question. While Slovenia and Croatia, as EU members, have an explicit obligation to fulfill the requirements defined by excessive deficit procedures, the stability of public finance is one of the cornerstones of economic policy conducted in other WB economies in the process of preparation of their economies for EU accession in the future period. Therefore, fights against unofficial economy and illicit tobacco trade are aims which deserve a high position on the list of WB governments' priorities. In addition to tax evasion related to illicit tobacco trade, the Croatian and Slovenian budgets lose a certain amount of tobacco tax because their residents go cross-border shopping in WB economies where tobacco taxation and prices are lower.

Tobacco excises are a relatively important item in total public revenues and total from $1 \%$ to even $2.5 \%$ of the official GDP in the WB area. The elimination of illicit tobacco trade could positively affect public finance not only in the short run due to an increase in tax revenues, but even more in the reduction of potential future health costs of smoking. In WB economies, health systems are dominantly public and financed from government budgets. Individuals buying illicit tobacco products do not participate in the financing of potentially high future costs related to the health risks of smoking. If low-priced illicit cigarettes disappear from the market, a certain percentage of persons could decide to quit smoking and, thus, reduce future health risks.

The limitation of this study is related to the fact that this survey method usually provides only a lower boundary of the scope of illicit tobacco trade. When participating in a survey which contains sensitive questions where respondents feel that the true answer could be considered as socially undesirable, they could choose to deliberately provide dishonest answers and hide their participation in buying tobacco on the gray market. In future research, if a more up-to-date survey is available, it will be possible to analyze the dynamics of the illicit tobacco trade. It is expected that the harmonization of the tax system and institutional development of WB economies could affect lower propensity to participate in illicit tobacco trade.

Author Contributions: All authors contributed equally in the writing of this paper. All authors have read and agreed to the published version of the manuscript.

Funding: This paper is part of the research project "Illegal Trade of Tobacco Products: Smuggling as Experienced along the Balkan Route-BalkanSmugg", funded by PMI IMPACT—a global grant initiative by Philip Morris International ("PMI") to support projects dedicated to fighting illegal trade and related crimes. In the performance of the research, the authors maintained full independence from PMI. The views and opinions expressed in this document are those of the authors and do not necessarily reflect the views of PMI.

Conflicts of Interest: The authors declare no conflicts of interest. The funders had no role in the design of the study; in the collection, analyses, or interpretation of data; in the writing of the manuscript, or in the decision to publish the results. 


\section{Appendix A}

Table A1. The distribution of answers from the respondents for the most important items on smoking prevalence and experience in illicit tobacco trade.

\begin{tabular}{|c|c|c|c|c|c|c|c|}
\hline & Croatia & Slovenia & Bosnia and Herzegovina & Serbia & Montenegro & Macedonia & Kosovo \\
\hline \multicolumn{8}{|c|}{ D1. Gender } \\
\hline Male & 1.425 & 1.483 & 1.500 & 1.500 & 1.554 & 1.490 & 1.510 \\
\hline Female & 1.575 & 1.526 & 1.500 & 1.500 & 1.446 & 1.510 & 1.490 \\
\hline \multicolumn{8}{|c|}{ Q5. Do you smoke cigarettes, some other tobacco products, or e-cigarettes? } \\
\hline Yes & 976 & 736 & 1.279 & 1.104 & 1.132 & 1.165 & 1.226 \\
\hline No & 2.024 & 2.272 & 1.721 & 1.896 & 1.868 & 1.835 & 1.774 \\
\hline \multicolumn{8}{|c|}{ Q6. Which of the following tobacco products do you use? } \\
\hline Industrially manufactured cigarettes & 770 & 613 & 87 & 1.005 & 889 & 1.098 & 1.212 \\
\hline Cut tobacco which I roll or stuff in cigarettes by myself & 269 & 176 & 18 & 130 & 250 & 65 & 47 \\
\hline Cigars & 52 & 42 & 2 & 5 & 2 & 1 & 0 \\
\hline Cigarillos & 11 & 26 & 0 & 1 & 3 & 0 & 0 \\
\hline Pipe tobacco & 7 & 12 & 0 & 0 & 2 & 0 & 3 \\
\hline E-cigarettes & 46 & 51 & 1 & 26 & 0 & 8 & 1 \\
\hline Something else & 2 & 8 & 0 & 0 & 0 & 0 & 0 \\
\hline \multicolumn{8}{|c|}{ Q9.1. How much of the product that you use do you usually smoke in one day? Industrially manufactured cigarettes (individual answers are grouped in classes) } \\
\hline From 1 to 10 & 344 & 344 & 561 & 324 & 249 & 374 & 63 \\
\hline From 11 to 20 & 348 & 233 & 497 & 557 & 496 & 512 & 921 \\
\hline Over 20 & 79 & 36 & 61 & 124 & 144 & 212 & 229 \\
\hline \multicolumn{8}{|c|}{ Q9.2. How much of the product that you use do you usually smoke in one day? Cut tobacco which I roll or stuff in cigarettes by myself (individual answers are grouped in classes } \\
\hline From 1 to 10 & 103 & 111 & 76 & 39 & 24 & 11 & 32 \\
\hline From 11 to 20 & 127 & 53 & 127 & 61 & 162 & 39 & 15 \\
\hline Over 20 & 40 & 12 & 32 & 30 & 64 & 15 & 0 \\
\hline \multicolumn{8}{|c|}{ Q10. Do you usually buy tobacco products or e-cigarette fillings in your country or abroad? } \\
\hline In the country & 905 & 695 & 1262 & 1101 & 1132 & 1165 & 1225 \\
\hline Abroad & 70 & 42 & 17 & 3 & 0 & 0 & 1 \\
\hline
\end{tabular}


Table A1. Cont.

\begin{tabular}{|c|c|c|c|c|c|c|c|}
\hline & Croatia & Slovenia & Bosnia and Herzegovina & Serbia & Montenegro & Macedonia & Kosovo \\
\hline \multicolumn{8}{|c|}{ Q11. Do you usually buy tobacco products at authorized stores or on the gray market? } \\
\hline At authorized stores & 888 & 698 & 1.010 & 1.022 & 816 & 1.115 & 1.149 \\
\hline On the gray market & 73 & 24 & 258 & 71 & 316 & 44 & 77 \\
\hline
\end{tabular}

Source: Authors' processing according to the survey data conducted by the Institute of Economics, Zagreb. 


\section{References}

1. Buturac, G. Beyond the Global Recession: Mutual Trade and Economic Convergence. Ekon. Pregl. 2013, 64, 303-326.

2. Broz, T.; Buturac, G.; Tkalec, M. To what extent does Croatia really cooperate with SEE countries in the fields of foreign trade, direct investment and tourism? Ekon. Istraž. 2015, 28, 879-906. [CrossRef]

3. Baldwin, J.R.; Gu, W. Trade Liberalization: Export-market Participation, Productivity Growth and Innovation. Oxf. Rev. Econ. Policy 2004, 20, 372-392. [CrossRef]

4. Cestepe, H.; Yildirima, E.; Bahtiyar, B. The Impact of Trade Liberalization on the Export of MENA Countries to OECD Trade Partners. Procedia. Econ. Financ. 2015, 23, 1440-1445. [CrossRef]

5. Ganić, M. The Integration of Western Balkan Economies in Global Economic Flows. In Resilkroad, 1st ed.; Bulut, M., Ed.; İstanbul Sabahattin Zaim Üniversite: İstanbul, Turkey, 2013; Volume 1, pp. 317-332.

6. Petrović, P.; Antevski, M.; Vesić, D. The International Competitiveness and Economic Integration. Econ. Organ. 2008, 5, 1-8.

7. Santos-Paulino, A.U. Trade Liberlaisation and Export Performance in Selected Developing Countries. J. Dev. Stud. 2010, 39, 140-164. [CrossRef]

8. Buturac, G.; Mikulić, D.; Palić, P. Sources of export growth and development of manufacturing industry: Empirical evidence from Croatia. Ekon. Istraž. 2019, 32, 101-127. [CrossRef]

9. Andreas, P. Criminalized Legacies of War: The Clandestine Political Economy of the Western Balkans. Probl. Post-Communism 2014, 51, 3-9. [CrossRef]

10. Bartlett, W. Europe's Troubled Region: Economic Development, Institutional Reform, and Social Welfare in the Western Balkans, 1st ed.; Routledge: Abingdon-on-Thames, UK, 2007; pp. 1-288.

11. Belloni, R. European integration and the Wester Balkans: Lessons, prospects and obstacles. J. Balk. Near East. Stud. 2009, 11, 313-331. [CrossRef]

12. Buturac, G. Država i ekonomija: Gdje je Hrvatska? Ekon. Pregl. 2014, 65, 513-540.

13. Buturac, G.; Ignjatijević, S. The Effects of Corruption on Innovation and Competitiveness: The Case of SEE Countries. In Proceedings of the Innovation, ICT and Education for the Next Generation-Thematic Proceedings, Novi Sad, Serbia, 26-27 May 2017; Soleša, D., Šimović, V., Rosi, B., Eds.; Faculty of Economics and Engineering Management: Novi Sad, Serbia, 2017; pp. 135-153.

14. World Health Organization (WHO). WHO Report on the Global Tobacco Epidemic: Monitoring Tobacco Use and Prevention Policies; World Health Organization: Geneva, Switzerland, 2017.

15. Varga, I.; Antunović, M.; Kristek, A. Pregled proizvodnje duhana u Hrvatskoj. In Proceedings of the 5th International Scientific/Professional Conference-Agriculture in Nature and Environment Protection, Osijek, Croatia, 4 June 2012; Stipešević, B., Sorić, R., Eds.; Osječki List: Osijek, Croatia, 2012; pp. 344-348.

16. Beljo, J.; Herceg, N.; Nurkić, H. Tobacco production in Bosnia and Herzegovina-From a great past to an uncertain future. Works Fac. Agric. Food Sci. Univ. Sarajevo 2016, 66, 49-60.

17. Peshevski, M.; Ameti, I.; Vukaj, O.; Petkov, R. Trading of Agricultural Products from Agrocomplex between Countries from Balkan Region. Econ. Agric. 2013, 60, 885-893.

18. World Health Organization (WHO). Framework Convention on Tobacco Control; World Health Organization: Geneva, Switzerland, 2003.

19. Allen, E. The Illicit Trade in Tobacco Products and How to Tackle it. World Cust. J. 2011, 6, 121-130.

20. Mashiri, E.; Sebele-Mpofu, Y.F. Illicit trade, economic growth and the role of Customs: A literature review. World Cust. J. 2015, 9, 38-50.

21. Bhagwati, J.N.; Hansen, B.A. Theoretical analysis of smuggling. Q. J. Econ. 1973, 87, 172-187. [CrossRef]

22. Sheikh, M.A. Smuggling, production and welfare. J. Int. Econ. 1974, 4, 355-364. [CrossRef]

23. Pitt, M.M. Smuggling and price disparity. J. Int. Econ. 1981, 11, 447-458. [CrossRef]

24. Norton, D.A.G. On the economic theory of smuggling. Economica 1988, 55, 107-118. [CrossRef]

25. Thursby, M.; Jensen, R.; Thursby, J. Smuggling, camouflaging, and market structure. Q. J. Econ. 1991, 106, 789-814. [CrossRef]

26. Merriman, D.; Yurekli, A.; Chaloupka, F.J. How big is the worldwide cigarette smuggling problem. In Tobacco Control in Developing Countries; Jha, P., Chaloupka, F., Eds.; Oxford University Press: Oxford, UK, 2000; pp. 365-395. 
27. Yurekli, A.; Sayginsoy, O. Worldwide Organized Cigarette Smuggling: An Empirical Analysis. Appl. Econ. 2010, 42, 545-561. [CrossRef]

28. Joossens, L.; Raw, M. From cigarette smuggling to illicit tobacco trade. Tob. Control 2012, 21, $230-234$. [CrossRef] [PubMed]

29. Cooper, A.; Witt, D. The linkage between tax burden and illicit trade of excisable products: The example of tobacco. World Cust. J. 2012, 6, 41-58.

30. Prieger, E.J.; Kulick, J. Cigarette Taxes and Illicit Trade in Europe. Econ. Inq. 2018, 56, 1706-1723. [CrossRef]

31. Joossens, L. Illicit Tobacco Trade in Europe: Issues and Solutions; PPACTE-Pricing Policies and Control of Tobacco in Europe, European Commission: Brussels, Belgium, 2011.

32. Calderoni, F. A new method for estimating the illicit cigarette market at the subnational level and its application to Italy. Glob. Crim. 2014, 15, 51-76. [CrossRef]

33. KPMG. Project Sun. A Study of the Illicit Cigarette Market in the European Union, Norway and Switzerland 2015 Results; KPMG: Zürich, Switzerland, 2015.

34. Calderoni, F.; Brenner, A.; Karayotova, M.; Rotondi, M.; Zorč, M. The Eastern Balkan Hub for Illicit Tobacco; Transcrime-Research Centre on Transnational Crime, Università Cattolica del Sacro Cuore: Milano, Italy, 2016.

35. Transcrime-Research Centre on Transnational Crime. The Factbook on the Illicit Trade in Tobacco Products; Transcrime-Universita degli Studi di Trento: Trento, Italy, 2013.

36. Transcrime-Research Centre on Transnational Crime. European Outlook on the Illicit Trade in Tobacco Products; Transcrime-Universita degli Studi di Trento: Trento, Italy, 2015.

37. CID Gallup. Illicit Cigarette Trade in Central America; CID Gallup: San Jose, Costa Rica, 2016.

38. Euromonitor International. Country Reports; Euromonitor International: London, UK, 2015.

39. Tourangeau, R.; Yan, T. Sensitive questions in surveys. Psychol. Bull. 2007, 133, 859-883. [CrossRef] [PubMed]

40. LaFaive, M.; Nesbit, T.; Drenkard, S. Cigarette Taxes and Smuggling: A 2016 Update, 1st ed.; The Mackinac Center for Public Policy: Midland, MI, USA, 2016; pp. 1-31.

(C) 2020 by the authors. Licensee MDPI, Basel, Switzerland. This article is an open access article distributed under the terms and conditions of the Creative Commons Attribution (CC BY) license (http://creativecommons.org/licenses/by/4.0/). 